\title{
Towards a better learning models through OCWs and MOOCs
}

\author{
A. Cordero, C. Jordán, E. Sanabria-Codesal and Juan R. Torregrosa
}

\author{
Universitat Politècnica de València
}

\begin{abstract}
Technological advances of XXth century have induced a profound change in society and, therefore, in the high education. Internet supposed a qualitative difference, as information and digital images flooded into homes around the world.

The Universitat Politècnica de València (UPV) is a medium sized university of Spain that has been involved in the development of digital video content (Polimedia) to support teaching processes for several years. Joint with Polimedia and other learning objects (virtual laboratories, applets, etc.), the UPV promoted the construction of OCWs. Along with the improvement of technology, MOOCs appeared as e-learning material.

In this work, we analyze the advantages and drawbacks of OCWs and MOOCs when they are used in our classroom. This experience has led us to incorporate in our methodology the flip teaching.
\end{abstract}

Keywords - Digital video, Flip education, Learning objects, MOOC, OCW, Polimedia.

\section{INTRODUCTION}

InCE the late 90s, the growth of technology, particularly related to internet, media, generating videos, etc. has grown exponentially. Besides, this change has been accompanied by a clear cost reduction and eases of handling different devices for creating, editing, quality videos and then hang on internet almost automatically. The technology has taken over our homes substantially changing society in which we live.

For our students this change has not existed. When they were born, technology was already at their fingertips. They do not conceive a world in which to communicate one has to go to a device attached to a table or going to the library for references. They are also used to have a lot of information quickly and in quality formats that simplify the ideas they convey. We think that they have lost concentration and deepening skills into a topic. When they encounter any problem (whose solution is not accessible by Internet) that requires more dedication and time, they abandon for lack of patience, because the analysis of the problems and search of their solutions are activities that today's society do not encourage.

In the educational field, to the observed change in our students, teachers introduced new technologies in education firstly by themselves and, later on, with institutional support adapting the teaching methodologies.

The improvement of technological media has facilitated video manipulation and the uploading to Internet, has led naturally to the massive generation of didactical videos, being YouTube a clear proof of this.

In particular the Universitat Politècnica de València (UPV) decided in 2003 to develop Polimedia, a system to record HD video learning objects using cheap audiovisual studios in a fast and simple way [1] that will be distributed offline-through a Learning Management System, in our case Sakai [2]. For supporting the teacher's work UPV started a support program named "Docencia en red" (teaching network) that gives both technical and economic support to encourage teachers to develop digital learning contents and to assess its quality.

This program is still open today. OpenCourseWare (OCW) plays an important role among these materials. "These provide free educational content you can use to enhance or refresh your knowledge or teach others". They could be formed only by text or text including links, videos, applets, etc. (see [3]). The OCW constitute the first major step to allow free access to knowledge from anywhere in the world having internet, so as to facilitate learning on-line. This implies to publish all of our course materials online and make them widely available to everyone.

Moreover, Internet is mainly used as a means of interactive communication, giving voice to the user for input, collaborate, interact, etc., allowing these contributions to be returned to other users in the form of shared knowledge. This is what is commonly known as Open Social Learning.

The OCW and the Open Social Learning have been the basin, during the last decade, for the appearance of the first Massive Open Online Course (MOOC) in institutions of higher education. A MOOC is an online course with the option of free and open registration, a publicly shared curriculum and opened outcomes [4]. Since the term was coined in 2008 to name a connectivism course offered by the University of Manitoba, a lot of Universities have offered courses under this denomination.

However, OCW, MOOC and, in general, any online learning material, is not only useful for accessing training outside the classroom. In this paper we show our experience when incorporating them to traditional subjects, commenting on the advantages and drawbacks that we have found.

\section{OCW AND MOOC}

The interaction between internet users with common interests has led to the generation of multiple manuals on specific topics. Easy access to these materials and their usefulness, has allowed many users to get visibility to their ideas and skills, which has led to an exponential growth of tutorials, videos, etc. that currently flood internet.

Education has not been immune to this technologic and social change, because we find today a wealth of information, either video or text, on how to solve all kind of problems, with different levels of complexity.

The increasing use of Open Social Learning is a clear evidence of the interest of internet users to meet their training needs online. Therefore educational institutions, where the appropriate technology was available, have conducted teaching projects in which a large number of students have been engaged. OCWs were the first organized teaching network.

The Open Education Consortium (OEC) [5] is a worldwide community of hundreds of higher education institutions and associated organizations committed to advancing open education and its impact 
on global education. The main goal of this consortium is to promote learning through the distribution and use of open free high-quality educational materials, organized into subjects, thus contributing to the free dissemination of knowledge.

Some Spanish universities, UPV among them, have created programs to encourage and support teachers that develop digital learning contents and to assess them regarding its quality. Among worldwide generated OCW subjects, in the first edition of the Awards of Excellence OEC (2011), the following subjects were awarded: "Actividad Fisica para la Salud" (Physical Activity for Health) taught by Pedro A. López-Miñarro at the University of Murcia, "Estructuras Matemáticas para la Informática II" (Mathematics for Computer Structures II) taught by the co-author of this work Cristina Jordan at the UPV and "Instituciones Básicas del Derecho Administrativo," (Basic Institutions of Administrative Law), taught by José Fernández at the University Carlos III of Madrid.

MOOCs are a new step in the evolution of this type of institutional online training [6]. Although their apparent similitude with OCWs, we would like to point out a significant difference: registration is required to access MOOCs because its goal is not only to present contents but also to carry out monitoring the student progress and being able to certify their use. Essentially these are packaged up pieces of learning that last a few weeks, are often put together by a top professor at a top university, and are available to anyone with a computer.

MOOCs are characterized by:

- Enrolment is unlimited

- Being online open

- Access and materials are completely free

- Teacher-student and student-student interaction are made via the forum, chat, e-mail, etc.

Currently, the certification of these courses works with the code of honor, but new ways for giving them an academic validity are under study. Among these new ideas being considered, we have those involving exams at partner institutions and also those using technological means to guarantee the authorship of the online tests during the course.

A first question is if the MOOCs are so great as they appear. Since 2012, the year in which they were known and used by the general public, there have been numerous statistics studies on its operation. Regarding the monitoring of these courses, only $10 \%$ of those enrolled finish them. On the other hand, they have not been useful to generalize higher education, since over $80 \%$ of those enrolled already had a higher qualification. The main problems are the lack of accessibility to Internet for students from poorer countries, the previous academic level or English language level, that is used in the most of courses [7].

A second question raised is if MOOCs with large-scale interactive participation and open access via web will replace face-to-face teaching in traditional universities, reducing the need of professors and universities. We believe that, by the comments of the previous paragraph, MOOCs will not pose a threat to classroom education, but on the contrary, they can be a useful tool in our classrooms. In the Fig. 1 we show the web of the MOOCs at UPV.

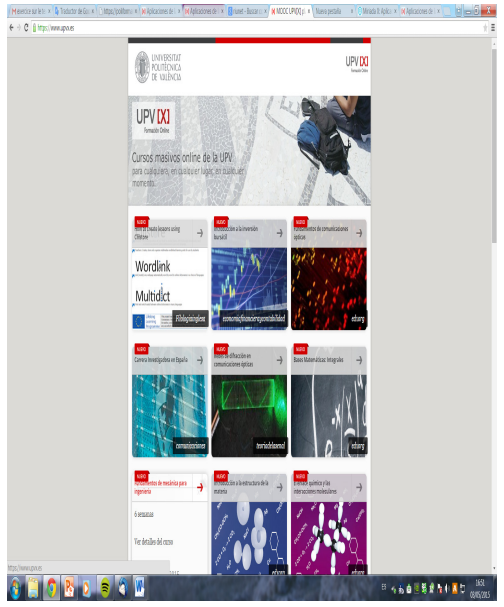

Fig.1. Screenshot of MOOCs of UPVX

\section{TOWARDS FLIP EDUCATION}

\section{A. Starting situation}

In college, although new technologies are used as a teaching support, an effort of comprehension and analysis is required. Just watching images is not enough to solve problems, it is necessary to adopt an active attitude. They should read and study texts, either on paper or file. It is hard to keep their attention, they easily get bored and mislead, and we observe that they need motivation to analyze any subject; they do not have patience to get results. In addition, they know that at any moment they can get immersed in the virtual world, getting away from what at that time seems boring and complicated. Moreover, working skill has also decreased; maybe because actual society takes care too much of them and tries to make their life too easy, or perhaps because they are used to think that things can be done with a click, or there is always a method to solve anything. So, to think for solving the problem is not necessary [8].

As a consequence, a common attitude observed during our years of teaching mathematics at a Computer Science and Engineering schools is the lack of interest in mathematics that, in general, show their students. Due to their lack of training in scientific understanding, they think that mathematical argumentations are hard to follow. In addition, they show difficulties in scientific expression, sometimes because the vocabulary is totally new. Finally, they sometimes show a poor level of motivation for the contents since they think that they are useless.

\section{B. Some changes are possible}

The previous considerations motivate us to conduct the following actions:

a) Introduce changes in the presentation of the contents of our subjects, showing real-life applications of the topics of the subject. This is done via modeling problems.

b) Modify the methodology in order to achieve the following goals:

- Make learning easier

- Students must detect their own mistakes or gaps

- Correct them in time

- Get, when they finish the course that they have learned beyond the concepts of the subject (which probably will be mostly forgotten, if they do not use them)

- Distinguish a logical reasoning from a wrong one

- Discover strategies for addressing to the problems more easily 
- Improve their scientific understanding and their expression skills, very useful throughout their professional lives

\section{How to carry changes out}

Taking into account the big amount of accessible online material, we pose ourselves about what we bring and what we should bring in the classroom. Nowadays, we can access to the knowledge with a mouse click. If our class is limited to data exposure, we are wasting our time. In addition, new methodological trends indicate that students must participate in class, working individually or in groups, not only outside the classroom, but under teacher guidelines.

The problem of implementing these educational activities is often the lack of time. So, if we plan to modify our classroom sessions, it may be preferable that the first contact of the student with the contents of the course takes place outside of it, in an autonomous manner, appropriate to their level. For this, we must assign pre-class activities in order to get that time in the classroom can be used in more interactive tasks. So, classroom work will reach higher levels of Bloom's Taxonomy [9], as is the analysis, which requires further debate and discussion (see Fig. 2). The interaction with the teacher and other colleagues then becomes more necessary. Furthermore, this type of teaching allows a more personalized assessment of students.

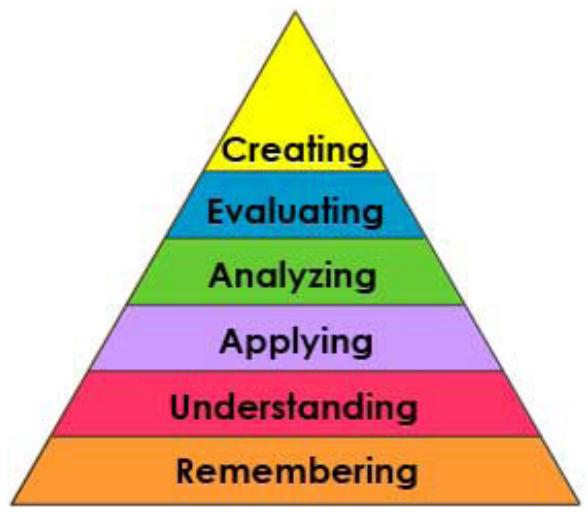

Fig.2. New version of Bloom's Taxomy

Our extensive teaching experience led us, gradually changing activities outside and inside the classroom. We initially led to record short videos (Polimedia) in order to facilitate the study and clarify questions that arise most commonly our students $[10,11,12]$. This set of videos was later given an OCW format [13]. In it, texts and applets are included in order to improve their skills in scientific language, as concepts presented in the video are also written. Later, in class, we combine the active lecture (where the student is involved with questions and / or answers), with activities that required the use of OCW. Shortly after, our university (UPV) embarked on the project to generate MOOCs where we participate actively [14]. Our published MOOC [15] was the final push to implement the flip teaching methodology, relying on the subject $\mathrm{OCW}$ and MOOC made.

\section{What is flip teaching?}

The methodology known as flipped classroom, where students have access before class to videos and interactive lessons created by teachers can turn the classroom into a place to solve problems, advance concepts, and participate in collaborative learning $[16,17,18]$.

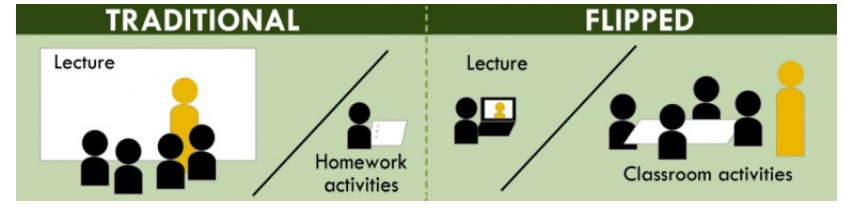

Fig. 3: Flipped Classroom

The difference with a more traditional approach lies mainly in that the acquisition of information is done by the student independently at their own pace, from the teaching materials given by the teacher. Consequently, part of the teachers work is to design activities for both a previous study and to be done in class, which also plays an important role as facilitator and driver of the teaching-learning process. In this way, teacher-students interaction increases in the classroom, to facilitate the joint development of generic and specific skills (see Fig. 3).

The methodology that we have conducted to reinforce learning is based in two key issues: student's daily work at home and a continuous feedback at the classroom with the professor and the classmate.

For all this matter, it has been essential for the students to have a detailed schedule with all the proposed tasks and activities, to dispose of good tools of communication with us, and to access to teaching materials and information quickly and orderly.

In our case, the online training materials that we use in the course is the OCW course "Estructuras Matemáticas para la Informática II", accessible from the website of the UPV [3] and MOOC "Aplicaciones de la Teoría de Grafos a la vida real" (Applications of Graph Theory to real life), active in the UPVX and EDX platform [15] (see Fig. 4). The tutorials that plan the work of students in each classroom session are available on the learning platform of the UPV, PoliformaT, member of Sakai project, where teachers and students share information.

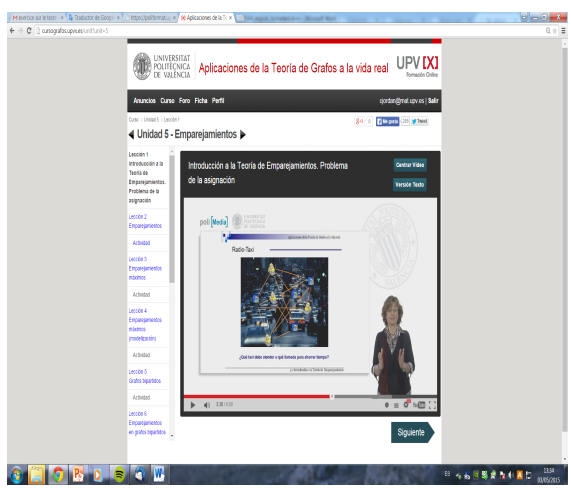

Fig.4. Screenshot of MOOC [18]

\section{FLIP TEACHING WITH MOOCs AND OCWs}

After application of the flip methodology over several academic years, we have come to the conclusion that despite it promotes a more meaningful learning, it has drawbacks that must be taken into account, in order to get a successful implementation. On the one hand, if the group is large it is more difficult to implement this methodology and to achieve active and ongoing collaboration of each student. The most common factors that hinder this collaboration, in our experience, are:

- Our students are not accustomed to the continuous assessment

- The workload of all subjects

- Extracurricular activities that hinder the first contact with the concepts that will be discussed in the classroom 
Moreover, any innovation in the teaching-learning process will have, at the beginning, a rejection by students, perhaps motivated by a different learning style to the prevailing since childhood.

Regarding the teacher, we emphasize the effort of developing appropriate educational material, either text or video. In addition, planning is a cornerstone of this methodology so it is essential to have tutorials for monitoring. In its writing we must pay special attention to both the suitable timing of the contents as to the workload at home: reviewing knowledge, view videos, solving exercises, etc.

On the other hand, in the classroom, the teacher should be very alert to the participation of each student. A good involvement in the classroom will yield students to be more motivated to study before each session, something necessary in this methodology [19].

In the particular case of working with MOOCs, usually students find videos more attractive than text. However, we found that in some cases, depending on the level and / or learning style of the students, they prefer to consult the $\mathrm{OCW}$, where the contents in text formats, applets, etc. can be found, in addition to videos.

\section{Conclusions}

Educational institutions have encouraged the creation of online learning materials in response to the new digital paradigm that society has experienced. Taking advantage of the accessibility features that Internet provides, several organizations have emerged as the Open Education Consortium, committed to advancing open education and its impact on global education, that envisions a world where everyone, everywhere has access to the education they need to build their futures. This is the origin of the OCW subjects, extended and complemented by MOOC courses.

In 2012 all voices pointed to the educational revolution that would assume these online courses, including voices warning about the possible disappearance of the face-to-face teaching universities as we know them today.

The statistics on enrollment, dropouts, results, show a less encouraging picture. We find some important drawbacks: many people around the world have no internet access, the problem of language, the difficulty to certificate the acquired knowledge, the lack of personal time to study (work, obligations, ...) which makes the dropout rate large, ...

However, the educational structure is changing and we must take all these initiatives, adapting them to our teaching. So, flip education movement is gaining strength, the many materials now available on line, well organized and structured (OCWs and MOOCs) to facilitate the pre-study class, allowing the classroom to become a forum for debate, discussion and presentation of ideas.

\section{ACKNOWLEDGMENT}

This work was supported by the Universitat Politècnica de València, PIME-B011

\section{REFERENCES}

[1] C. Turro, A. Cañero and J. Busquets, "Video Learning Objects Creation with Polimedia", IEEE International Symposium on Multimedia, 2010, pp. 371-376.

[2] Sakai Project. [On line]. Available: https://sakaiproject.org

[3] C. Jordán. (2010). Estructuras Matemáticas para la Informática II [On line]. Available: http://www.upv.es/ocwasi/2010/6024

[4] P. Pernías Peco and S. Luján Mora. Los MOOC: orígenes, historia y tipos. [On line]. Available:

[5] http://www.centrocp.com/los-mooc-origenes-historia-y-tipos
[6] Open Education Consortium. [On line]. Available: http://www. oeconsortium.org

[7] Instituto Nacional de Tecnologías Educativas y de Formación del Profesorado (INTEF). intefmooc. [On line]. Available: http://educalab.es/ $\underline{\text { mooc }}$

[8] K. Vázquez. (2014, Oct 9) ¿Qué fue de la revolución MOOC? [On line]. Available: http://economia.elpais.com/economia/2014/10/08/ actualidad/1412783861 083138.html

[9] A. Cordero, C. Jordan and J. R. Torregrosa. "How do current students face math problems solving?" Proceedings of 9th International Technology, Education and development Conference, INTED, Madrid, 2015, pp. 47164721.

[10] R. C. Overbaugh and L. Schultz. Google Tools to Support Bloom's Revised Taxomy [On line]. Available: http://ww2.odu.edu/educ/roverbau/ Bloom/blooms taxonomy.htm

[11] C. Jordán, "Utilización correcta e incorrecta de los ficheros Polimedia", Actas de la JIDINF'09, 2009, Valencia.

[12] C. Jordán and J. R. Torregrosa, "Docencia en red: un paso adelante en el uso de nuevas tecnologías", Actas de las VI Jornadas de redes de investigación en docencia universitaria, pp.726-735, 2008, Alicante.

[13] C. Jordán and J. R. Torregrosa, "Los objetos de aprendizaje y el nuevo contexto educativo", Actas del V Congreso Iberoamericano de Docencia Universitaria, 2008, Valencia.

[14] C. Jordán and J. R. Torregrosa, "Las OCW en el nuevo contexto educativo", Actas de las VIII Jornadas de Redes de Investigación en Docencia Universitaria, pp. 2344-2357, 2010, Alicante.

[15] I. M. Despujol, C. Turró, J. Busquets and A. Cañero, "Analysis of demographics and results of student's opinion survey of a large scale MOOC deployment for the spanish speaking community", IEEE Frontiers in Education Conference, 2014, pp 702-709.

[16] A. Conejero and C. Jordán, MOOC UPVX Aplicaciones de la Teoría de Grafos [On line]. Available: http://cursografos.upvx.es

[17] J. Bergmann and A. Sams, "Flip Your Classroom: Talk to Every Student in Every Class Every Day". International Society for Technology in Education, 2012.

[18] B. Tucker, "The flipped classroom". Education Next, 12(1), 2012, pp. 8283.

[19] University of Washington. Flipping the Classroom [On line]. Available: http://www.washington.edu/teaching/teaching-resources/engagingstudents-in-learning/flipping-the-classroom

[20] C. Jordán, M.J. Pérez and E. Sanabria, "Investigación del impacto en un aula de matemáticas al utilizar flip education", Pensamiento Matemático vol. IV, no . 2, 2014, pp.9-22.

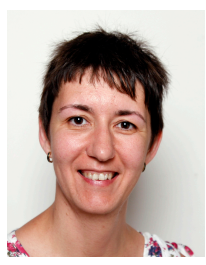

Alicia Cordero serves as an Assistant Professor at the Department of Applied Mathematics. She obtained her $\mathrm{Ph}$. D. degree in dynamical analysis of three-dimensional manifolds in 2003. She is a Member of the Institute of Multidisciplinary Mathematics of the Universitat Politècnica de València, Spain. Cordero published some papers on handling decomposition, links of periodic orbits, and their applications to celestial mechanics. Her research interests are in the areas of dynamical systems and numerical analysis. She has been working on a number of different problems, which fall under iterative methods for solving nonlinear equations or nonlinear systems and dynamical studies of rational functions.

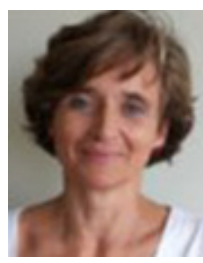

Cristina Jordán Lluch, asistant Professor at the Department of Applied Mathematics at ETS of Computer Engineering at Universitat Politècnica de València, where teaches Discrete Mathematics and Graph Theory. Her research interest include matrix completion and mathematical modelling by using graphs. She has participated in a large number of conferences and projects about teaching innovation. Nowadays she coordinates the first course of the Degree in Computer Engineering at Universitat Politècnica de València. In 2011 she received one of the six international prizes awarded by the Open Courseware Consortium for excellence in Opencourseware (OCW) for his course Mathematics II for Information Structure on Graph Theory. 


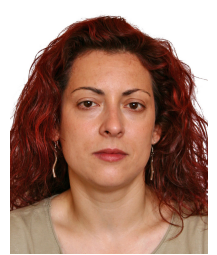

Esther Sanabria Codesal, Assistant Professor at the Polytechnic University of Valencia's Department. Applied Mathematics at the School of Engineering where she teaches calculus. Her research includes the theory of singularities applied to geometry and mathematical modeling based on graphs. She has participated in numerous conferences and educational innovation projects for new students and secondary education. Currently she is working on various projects of educational innovation.

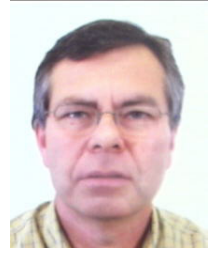

Juan R. Torregrosa holds the position of a Full Professor at the Department of Applied Mathematics and Member of the Institute of Multidisciplinary Mathematics of the Universitat Politecnica de Valencia, Valencia, Spain. He performed his Ph.D. degree in 1990 on geometrical properties in Banach spaces and published in the 1990s some papers about locally convex spaces and Banach spaces. Since 1995 Torregrosa has participated uninterruptedly as Researcher and/or Lead Researcher of several research competitive Spanish and European projects granted with public funds. Early in the century, he began working in the areas of linear algebra, matrix analysis, and combinatory. He is the coauthor of more than 120 papers published in major international peer-reviewed multidisciplinary scientific journals indexed in JCR (Mathematics and Applied Mathematics). He has been the Advisor/ Coadvisor of 7 Ph.D. dissertations and more than 30 Master dissertations. Five of these $\mathrm{Ph} . \mathrm{D}$. dissertations have been defended during the last 10 years. $\mathrm{He}$ has been the Lead Guest Editor of several peer-reviewed international journals. At this moment, his main research interests are in the areas of matrix analysis, numerical analysis, and the dynamical study of iterative methods. Recently, he has been working on a number of different problems, which fall under iterative methods for solving nonlinear equations or nonlinear systems and dynamical studies of rational functions. 